\title{
Short-term movement of barramundi in a seasonally closed freshwater habitat
}

\author{
M. R. Heupel ${ }^{1, *}$, D. M. Knip ${ }^{2}$, P. de Lestang ${ }^{3,4}$, Q. A. Allsop ${ }^{3}$, B. S. Grace Gr, $^{3,5}$ \\ ${ }^{1}$ Australian Institute of Marine Science and School of Earth and Environmental Sciences, James Cook University, Townsville, \\ Queensland 4811, Australia \\ ${ }^{2}$ Fishing and Fisheries Research Centre, School of Earth and Environmental Sciences, James Cook University, Townsville, \\ Queensland 4811, Australia \\ ${ }^{3}$ Department of Regional Development, Primary Industry, Fisheries and Resources, Darwin, Northern Territory 0801, \\ Australia \\ ${ }^{4}$ Sinclair Knight Merz Consulting, Perth, Western Australia 6001, Australia \\ ${ }^{5}$ Ecology Results, Blackwood, South Australia 5051, Australia
}

\begin{abstract}
Despite a broad Indo-Pacific distribution, the movement patterns of barramundi Lates calcarifer have gone largely unstudied, particularly in freshwater systems. This study examined the short-term movement and dispersal patterns of 60 barramundi in a seasonally closed freshwater system in 2 seasons (warm and cool). Data indicated that individuals generally moved small distances during up to $18 \mathrm{~d}$ of monitoring and that size was not a factor in movement patterns. Individuals moved farther and had larger activity spaces in the cool season than in the warm season, indicating different behaviour between seasons in this freshwater habitat. However, in both seasons, individuals remained in the permanently flooded sections of the billabong with limited movement into seasonally flooded regions. Further examination of long-term presence and movements of freshwater barramundi populations is required, but these data provide insight into short-term movements in a freshwater system.
\end{abstract}

KEY WORDS: Telemetry $\cdot$ Seasonal $\cdot$ Movement $\cdot$ Freshwater

Resale or republication not permitted without written consent of the publisher

\section{INTRODUCTION}

Freshwater systems around the world are coming under increasing threat because of human activities (e.g. Bayley 1989, Makrakis et al. 2007). In addition, tropical river systems are subject to large seasonal changes that contribute to the elasticity of resource use, feeding, breeding and habitat use strategies of their inhabitants (Douglas et al. 2005, Perna \& Pearson 2008, Rayner et al. 2010). Seasonal rainfall causes the expansion and contraction of habitat, which forces species to adapt to different conditions seasonally, ultimately affecting fish assemblage structure and species richness in different stretches of river habitat (e.g. Pusey et al. 1995, Galacatos et al. 2004, Perna \& Pearson 2008). Loss of habitat during the dry season typically forces species to take refuge in deep channels or waterholes, which concentrate predator and prey species. This can create a strong top-down effect in the system, with predators often shifting to omnivory as prey base is reduced (Douglas et al. 2005, Rayner et al. 2010).

Changing hydrological conditions result in differences in the prey base that result in the support of large predators. Changes in water level lead to changes in available habitat and access to sources of primary production (Douglas et al. 2005), but physical disturbance to habitat during large freshwater flows can also have strong impacts on habitat and thus prey abundance. These observations have led to differing conclusions about tropical river systems. Some authors suggest that prey base is increased in the wet season due to some species breeding after rainfall begins (e.g. Douglas et al. 2005), whereas others suggest that prey base is reduced because of wet season flooding, causing habitat disturbance and reductions in productivity 
(Rayner et al. 2009). Although the broad impacts of seasonal hydrological changes are well studied, how species respond to these changes requires further study (Arrington \& Winemiller 2006, Castello 2008).

The barramundi Lates calcarifer is a large predatory fish found in tropical Australia and within the IndoPacific region. Barramundi were generally thought to follow a catadromous life history (i.e. Moore \& Reynolds 1982, Pender \& Griffin 1996); however, recent research into otholith microchemistry has revealed flexibility in its life-history strategy, with some individuals staying entirely within marine or freshwater environments and others moving between the two habitats (McCulloch et al. 2005, Milton et al. 2008). This species is also known to use fully freshwater systems that can become landlocked in dry seasons (Griffin 1994).

Existing data on barramundi movement have largely been determined by tag-recapture programs. Tagging programs in Papua New Guinea and Australia reported the majority of recaptures within $15 \mathrm{~km}$ of their release location, with limited numbers of individuals moving larger distances (Moore \& Reynolds 1982, Russell \& Garrett 1988). River-based movement data for various freshwater species indicate downstream movement patterns, possibly triggered by environmental conditions such as temperature or water level (e.g. Griffin 1987, Fernandes 1997, Saint-Paul et al. 2000). Downstream movement is often considered to be related to spawning, with juveniles showing less downstream movement (Griffin 1987, Fernandes 1997). Recapture of barramundi near their release location has, however, led to contradictory conclusions that individuals return to specific sites after spawning (Moore \& Reynolds
1982) or remain resident in coastal regions and do not move from these locations (Davis 1986).

Barramundi populations display varying movement patterns, even altering their behaviour to fit the environmental conditions present (Robins et al. 2005). It is possible that this variability is a function of habitat differences, but it could also be genetically derived. Keenan (1994) revealed 16 distinct genetically and reproductively isolated subpopulations of barramundi, and these subpopulations could also have different movement and behaviour patterns. These studies suggest that high variability exists in life history, ecology and movement patterns of barramundi populations.

Although it is apparent that barramundi can adapt to varying conditions, it is unclear whether behaviour or habitat use changes in different seasons or whether use of regions is consistent and predictable. Here we examined short-term movement patterns of individuals within a seasonally closed freshwater system in 2 different seasons to define whether movement and dispersal within this habitat differed by individual or season.

\section{MATERIALS AND METHODS}

All individuals were captured and released in Mission Billabong $\left(13^{\circ} 46^{\prime} \mathrm{S}, 130^{\circ} 27^{\prime} \mathrm{E}\right), 150 \mathrm{~km}$ southwest of Darwin, Northern Territory, Australia (Fig. 1). Mission Billabong is a freshwater body within the Daly River catchment and, as such, is subject to seasonal differences in temperature and water flow with distinct wet (warm) and dry (cool) seasons. Individuals were captured by rod and reel angling using artificial lures

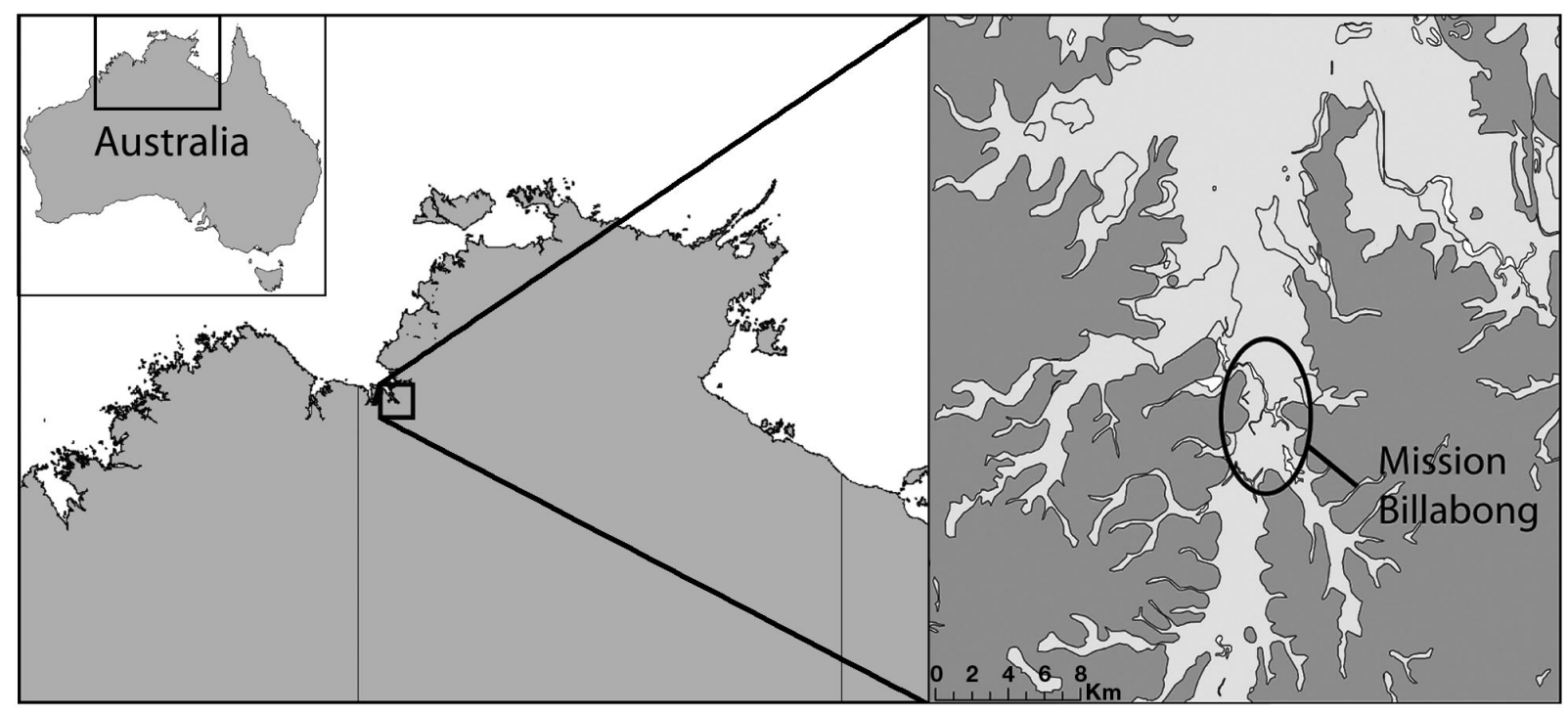

Fig. 1. Study site, indicating the Mission Billabong portion of the Daly River, Australia, where barramundi were sampled. Right panel: white, permanently flooded areas; light grey, intermittently flooded areas; dark grey, elevated areas 
(mean \pm SE landing time was $52 \pm 4 \mathrm{~s}$ ). Captured fish were restrained in a landing net, brought aboard the vessel for hook removal, immediately wrapped in a wet cloth and restrained in a soft sponge-lined cradle. Total length (TL) of individuals was measured to the nearest $\mathrm{cm}$, and individuals were fitted with an external dart tag for identification purposes (Hallprint dart tag) and then with a radio transmitter (Advanced Telemetry Systems F2030) to facilitate tracking. Transmitters were $15 \times 60 \mathrm{~mm}$ with a $300 \mathrm{~mm}$ antenna, modelled on those used by Osborne \& Bettoli (1995) and attached through the muscle at the base of the dorsal fin via absorbable sutures (Ethicon chromic gut). Sutures were knotted and secured with fast-acting glue to ensure retention. Use of absorbable sutures ensured the transmitter would eventually release from the individual and float to the surface to facilitate recovery. Fish were handled for a mean time of $141 \pm 5 \mathrm{~s}$. Each transmitter was tuned to a unique frequency and was equipped with a mortality sensor, which doubled the signal pulse if the transmitter was stationary for a period exceeding $9 \mathrm{~h}$.

Individuals were released within the billabong and re-located once per day, when possible, with a $2 \mathrm{MHz}$ receiver (Advanced Telemetry Systems Receiver R2000) during each of 2 seasons. The warm season was monitored from 4 to 24 November 2002, and the cool season was monitored from 22 July to 9 August 2003. When an individual was located, the transmitter number and GPS location were recorded. Because of high turbidity, re-location by sighting individuals could only be completed for a small number of individuals situated close to the surface $(\sim 150 \mathrm{~cm}$ depth). For the majority of the tagged fish not sighted, re-location of the transmitter within Mission Billabong over consecutive days represented a live tagged fish (de Lestang et al. 2004, in press). Individuals were re-located each day for up to $18 \mathrm{~d}$ in each season. Unique individuals were monitored in each of the seasons.

Analysis. Distance between consecutive re-locations of each individual was examined to define the extent of movement of individuals. Analysis of covariance (ANCOVA) was used to examine the relationship between distance moved and fish size, time at liberty and season. Data were normalised by $\log (x+1)$ transformation. Activity space analysis was completed based on the total number of re-location points for each individual. A minimum convex polygon (MCP) was calculated for each individual to define the extent of movement during the monitoring period. ANCOVA was used to examine the effects of fish size and season on activity space size. The distance all individuals were dispersed from one another on specific days was also calculated. Dispersal distance was measured using MCP calculations of all individuals on each monitoring date. This was used to define whether individu- als were closely associated or spread farther apart and whether that distribution changed through time. ANCOVA was used to examine the effects of time at liberty and season on dispersal distance.

\section{RESULTS}

Sixty barramundi were fitted with radio transmitters: 29 in the warm season, 31 in the cool season. Individuals ranged in size from 38 to $100 \mathrm{~cm} \mathrm{TL}$, and individuals captured in the warm season were significantly smaller (38 to $70 \mathrm{~cm} \mathrm{TL}$, mean $53 \mathrm{~cm}$ TL) than those in the cool season (45 to $100 \mathrm{~cm} \mathrm{TL}$, mean $61 \mathrm{~cm} \mathrm{TL}$; $t$-test, $t=1.67, \mathrm{p}<0.01)$.

Daily re-locations revealed that most individuals moved shorter distances in the warm season. Only one individual showed movement greater than $1 \mathrm{~km}$ from the release location and $65 \%$ of individuals moved less than $500 \mathrm{~m}$ from their release location (Fig. 2a). Movement of individuals in the cool season differed, with

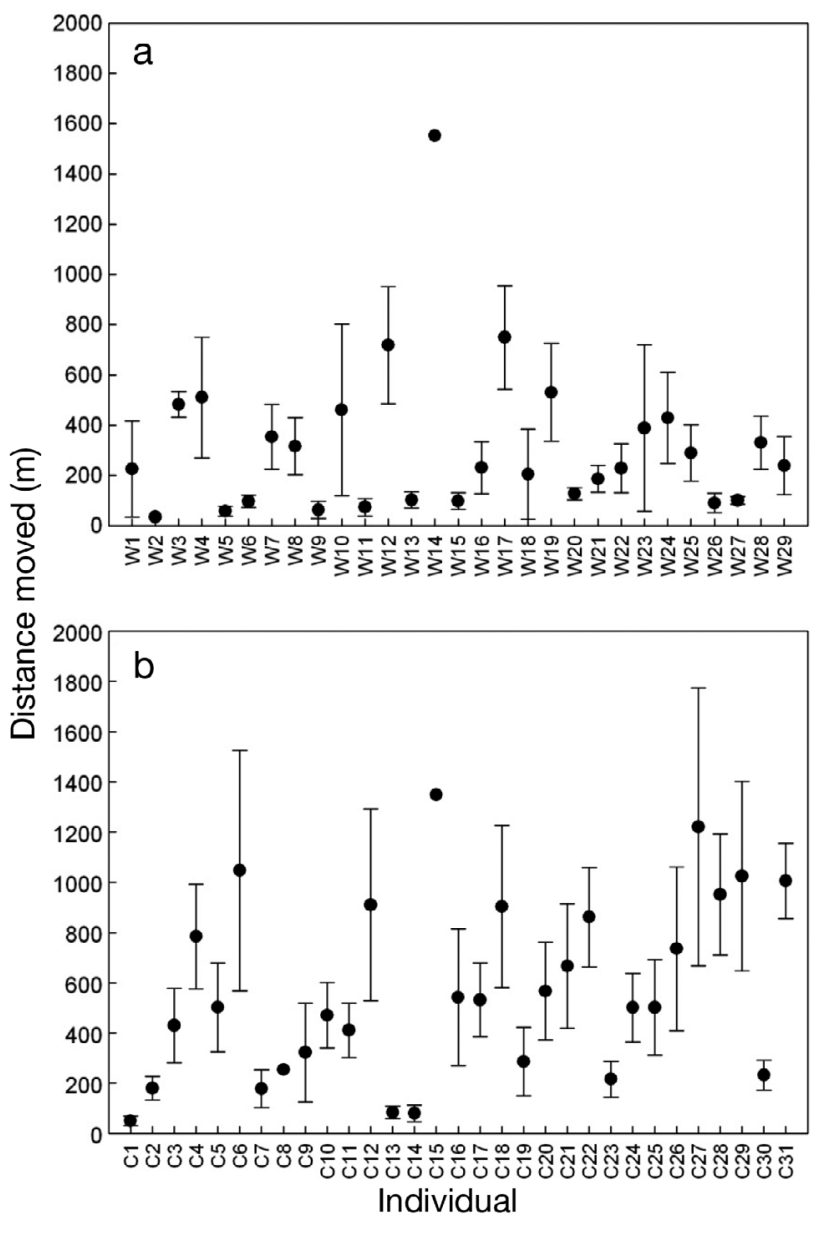

Fig. 2. Lates calcarifer. Mean distance moved by day for individual barramundi after release in Mission Billabong for (a) warm (W) and (b) cool (C) seasons. Error bars are \pm SE 
several individuals moving over $1 \mathrm{~km}$ from their release location, whereas only $32 \%$ of individuals moved less than $500 \mathrm{~m}$ (Fig. 2b). Distance moved was significantly different between seasons (ANCOVA, $F=14.67$, $\mathrm{df}=1,430, \mathrm{p}<0.0001$ ), but there was no significant relationship between distance moved and size of the individual $(F=2.64, \mathrm{df}=1,430, \mathrm{p}=0.105)$. Distance moved also increased with days at liberty $(F=5.61, \mathrm{df}=$ $1,430, p=0.018)$. Examination of distance moved by date revealed that the mean distance moved was $400 \mathrm{~m}$ or less on all but one day for individuals in the warm season (Fig. 3a). Persistence for periods of at least $11 \mathrm{~d}$ suggests that individuals had not commenced any long-range movements following capture, tagging and release. Conversely, in the cool season, less than half of the days revealed movements of $400 \mathrm{~m}$ or less. The period of 6-7 August showed the greatest movements, with mean distances travelled of 1612 and $1131 \mathrm{~m}$, respectively, followed by a final day of low movement $\left(\right.$ mean $=397 \mathrm{~m}_{i}$ Fig. 3b).

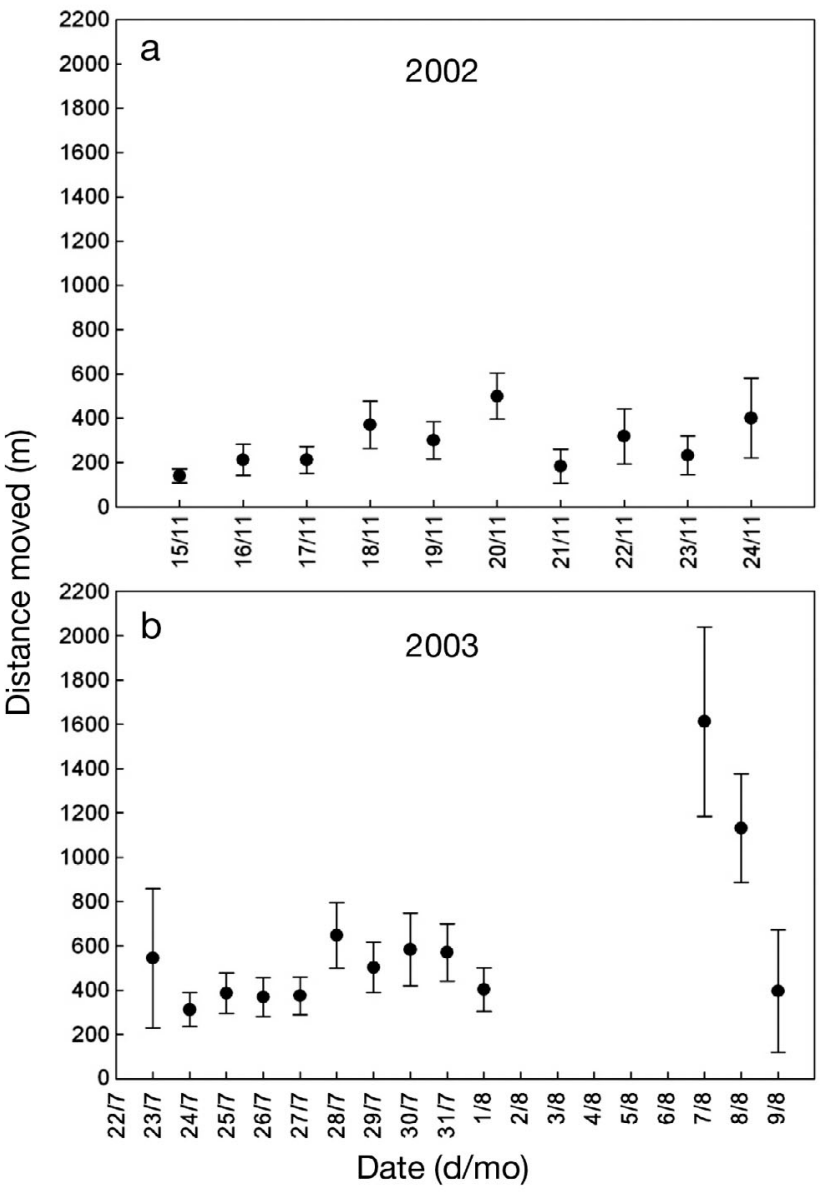

Fig. 3. Lates calcarifer. Mean distance moved over time by all monitored barramundi in Mission Billabong for (a) warm and (b) cool seasons. Missing points indicate days when individuals were not re-located. Error bars are $\pm \mathrm{SE}$
Estimates of activity space were highly variable between individuals and seasons. Activity space size was significantly related to season but not to individual length (ANCOVA, season: $F=10.67$, df $=1,51, \mathrm{p}<$ 0.001; length: $F=0.005$, df $=1,51, \mathrm{p}=0.942$ ). All MCPs for individuals in the warm season were below $1 \mathrm{~km}^{2}$ (Fig. 4a). MCPs for the cool season were larger, with a maximum of $2.4 \mathrm{~km}^{2}$ and most below $1.5 \mathrm{~km}^{2}$ (Fig. $4 \mathrm{~b}$ ), suggesting that individuals in the cool season moved more widely and used larger areas than those in the warm season.

Dispersion of individuals supported activity space observations, with individuals in the warm season revealing a stable dispersion distance among individuals (Fig. 5a), indicating that individuals were not widely dispersed. In the cool season, however, individuals dispersed farther apart through time, with greatest distances apart occurring in early August (Fig. 5b), thus individuals were more widespread in the cool season and moved farther apart post-release. Analysis of

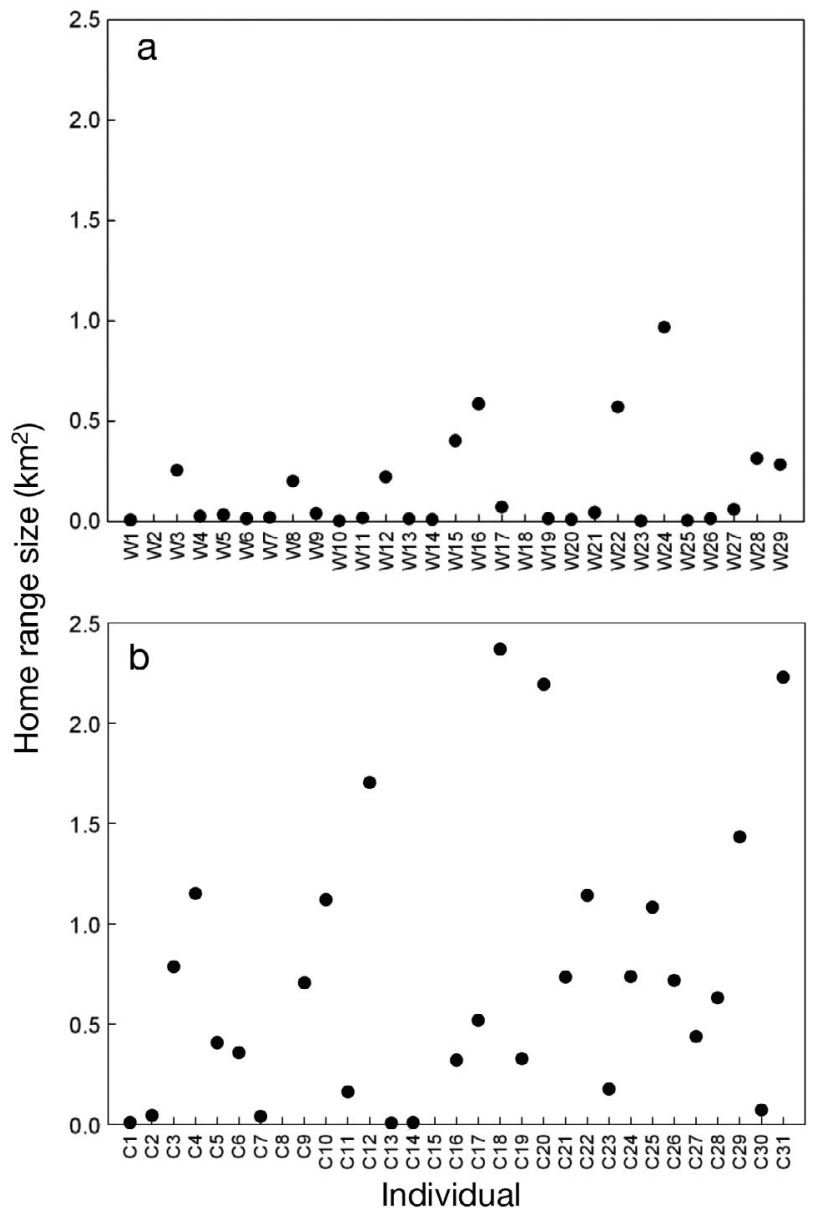

Fig. 4. Lates calcarifer. Estimates of activity space size for barramundi monitored within Mission Billabong for (a) warm and (b) cool seasons 


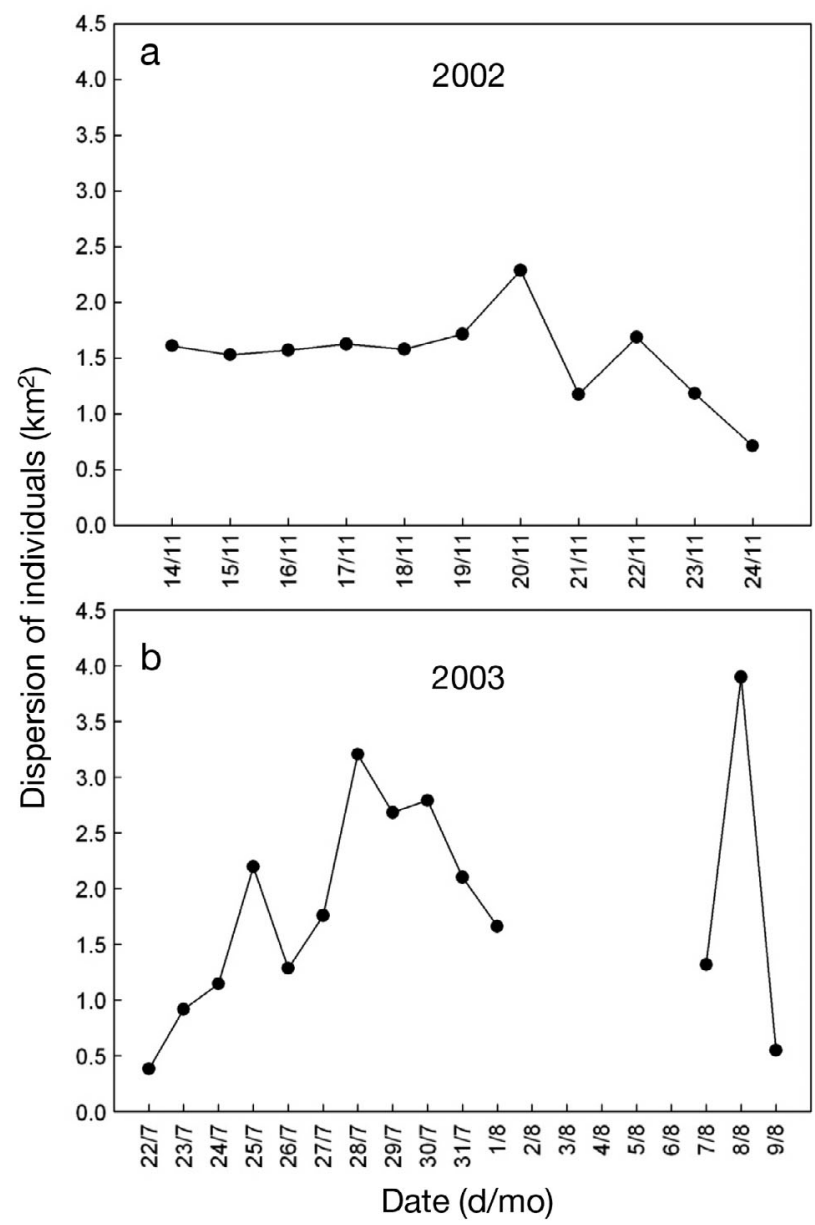

Fig. 5. Lates calcarifer. Dispersal distance of barramundi through time for (a) warm and (b) cool seasons. Missing points indicate days when individuals were not re-located

dispersal data revealed no significant differences by season or days at liberty (ANCOVA, season: $F=0.53$, $\mathrm{df}=1,22, \mathrm{p}=0.475$; days: $F=1.69, \mathrm{df}=1,22, \mathrm{p}=0.207$ ). Although dispersal distances were not significant, location of individuals changed through time, altering the amount of area between individuals and the region of the freshwater system used. For example, locations during the warm season were mostly in the central portion of the site (Fig. 6), whereas in the cool season individuals ventured farther north (Fig. 7). However, individuals in both seasons remained in permanently flooded regions and tended not to move into seasonally flooded areas of the billabong.

\section{DISCUSSION}

The use of seasonally fluctuating freshwater environments has been examined by monitoring species abundance and richness (e.g. Pusey et al. 1995, Perna
\& Pearson 2008, Rayner et al. 2010), but none of these studies have tracked the presence and movements of individuals. Abundance data suggest that seasonal changes play an important role in distribution, habitat requirements, habitat partitioning and habitat preference of resident fishes. However, Robins et al. (2005) suggest that barramundi are highly adaptable to the extent of varying life history characteristics within a given environment. This suggests that barramundi may not need to move in response to changing circumstances as other species may do (e.g. Perna \& Pearson 2008). The results obtained in this short-term analysis of movement indicate that barramundi used consistent regions of habitat in both warm and cool seasons, suggesting that they can cope with changing conditions. There was also limited evidence of movement beyond the permanently flooded regions of the billabong, further suggesting consistent use of space or some level of site attachment.

Previous research suggests that barramundi are most active during the warmer wet season months (e.g. Moore \& Reynolds 1982, Griffin 1987, Russell \& Garrett 1988). However, barramundi in Mission Billabong did not move large distances in the warm season. Rainfall of $72 \mathrm{~mm}$ was recorded during the monitoring period (Australian Bureau of Meteorology, www.bom.gov.au), signalling the beginning of the wet season, but limited rainfall and lack of freshwater flow may have delayed movement. Moore \& Reynolds (1982) reported that migration of barramundi was triggered by water level and flow and Dunstan (1962) concluded that during a poor wet season there may not be sufficient flow to release landlocked populations. However, in the present study, individuals may not have moved large distances for a variety of reasons. One potential explanation is that a portion of barramundi populations remain resident within freshwater habitats throughout their life. Griffin (1994) reported no seasonal movement of barramundi within a billabong and Davis (1986) suggested that a portion of freshwater populations may not move to the coast, which may indicate that lack of movement is a common characteristic of these populations or that individuals rely on very specific cues to direct movement. The duration of sampling also may be an issue in these results, and longer-term monitoring may reveal broader movement patterns.

Individuals moved greater distances during the cool, dry season than in the warm, wet conditions. Reasons for larger movements in the cool season are unclear, but may be related to prey abundance and predatory behaviour, as noted in freshwater systems in South America (e.g. Fernandes 1997, Rodriguez \& Lewis 1997, Saint-Paul et al. 2000). In these systems, movements have been related to feeding requirements during dry periods. For example, Rodriguez \& Lewis 

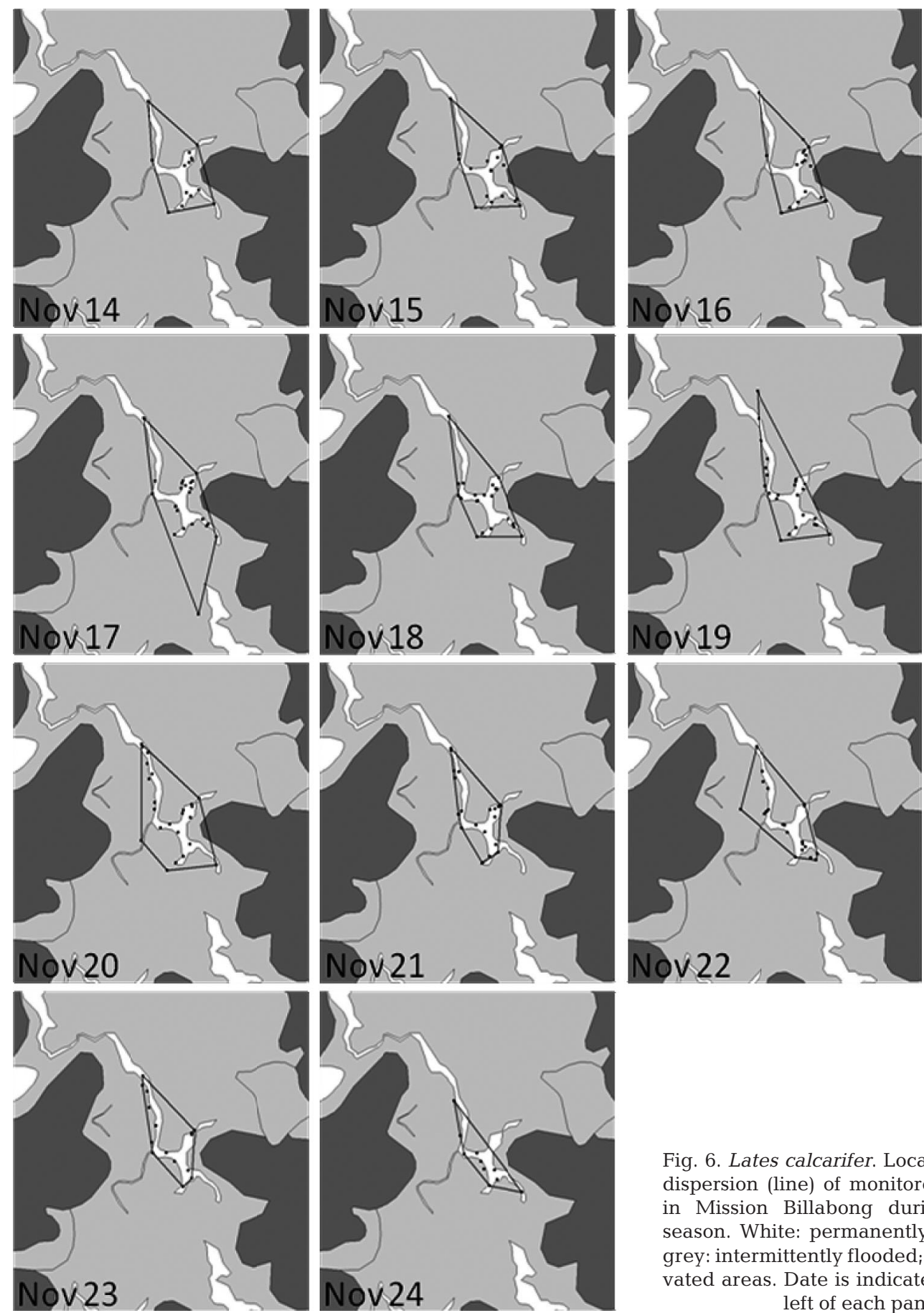

Fig. 6. Lates calcarifer. Location (dots) and dispersion (line) of monitored barramundi in Mission Billabong during the warm season. White: permanently flooded; light grey: intermittently flooded; dark grey: elevated areas. Date is indicated in the lower left of each panel

(1997) suggested that fish assemblages were heavily related to water transparency and feeding strategy. As water clarity declines during the dry season, behaviour of visual hunters may be altered. Thus, despite decreased water levels pooling resources, prey may become limited during these months and alterations to water quality and clarity may require individuals to move greater distances to locate prey. At least some freshwater populations spawn late in the dry (cool) season or early wet (warm) season, which would provide an increase in potential prey during the warm season as juveniles recruit to populations (e.g. Balcombe et al. 2006). Tedesco et al. (2008) also reported that floodplain inundation can enhance recruitment by improving the feeding environment for larvae, resulting in clear responses to hydrological seasonality in 

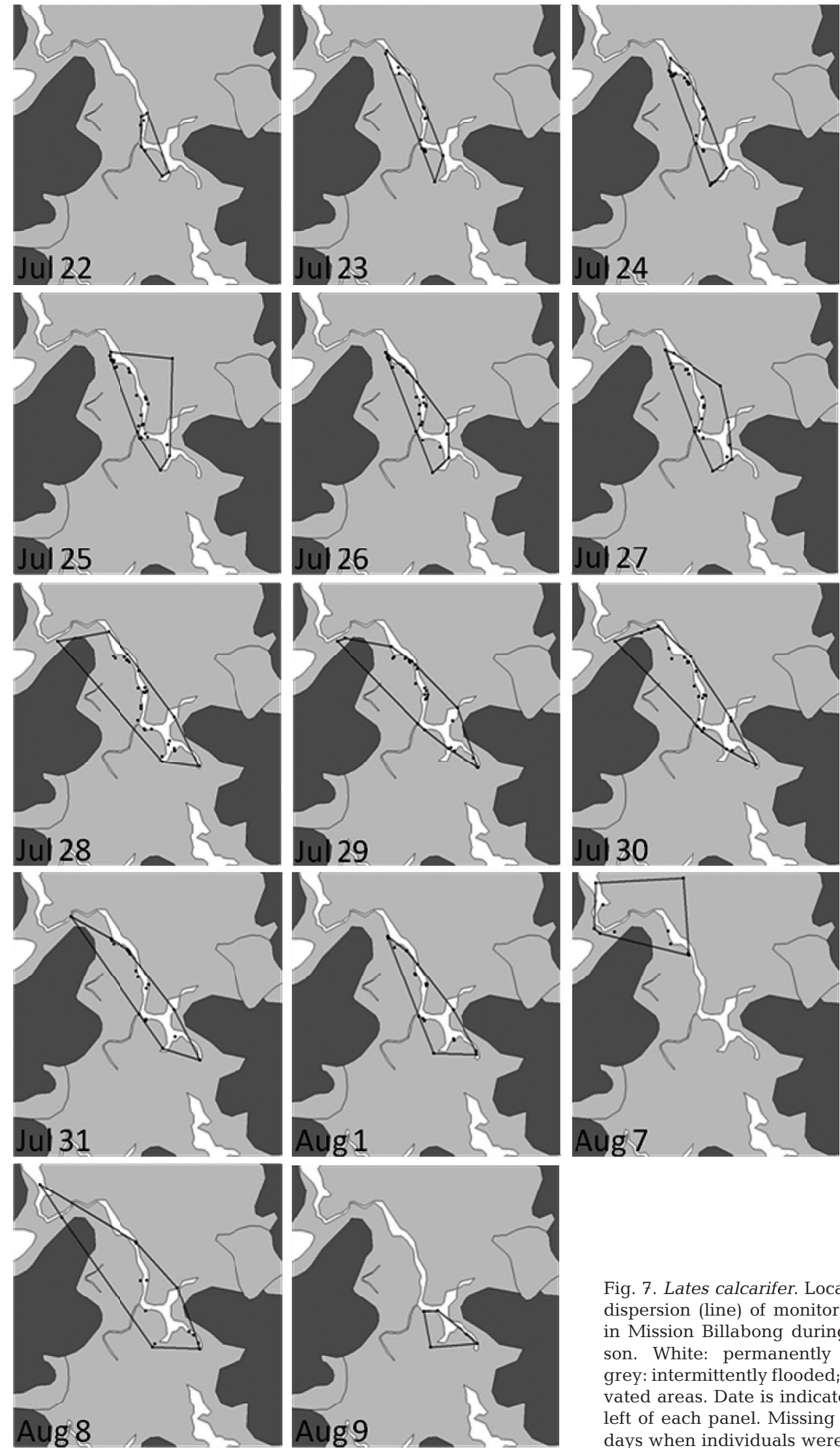

Fig. 7. Lates calcarifer. Location (dots) and dispersion (line) of monitored barramundi in Mission Billabong during the cool season. White: permanently flooded; light grey: intermittently flooded; dark grey: elevated areas. Date is indicated in the lower left of each panel. Missing points indicate days when individuals were not re-located 
tropical river populations. Thus, in the warm season prey may be more abundant or move more on the currents of flowing water, allowing freshwater predators to remain in one location and ambush prey that move into or through an area.

Differences in the amount of movement by barramundi between the 2 seasons were apparent in activity space estimates, with higher values from the cool season. MCP estimates revealed that some individuals tended not to move far $\left(<1 \mathrm{~km}^{2}\right)$ whereas others used areas as large as $1.5 \mathrm{~km}^{2}$ in the warm season and $2.5 \mathrm{~km}^{2}$ in the cool season. Activity space estimates near zero indicate that individuals can remain resident within a specific location for periods of at least a week. There was no evidence that movement patterns were related to size of individuals, indicating uniform movement among sizes. These data suggest that during the course of a week barramundi are likely to use anywhere from 0 to $2 \mathrm{~km}^{2}$ of habitat. In contrast, differences in distance moved at the end of cool season sampling are difficult to define. No obvious difference in physical parameters was recorded (P. de Lestang \& Q. A. Allsop unpubl. data) during this period to explain dispersal of individuals in early August. No rainfall was recorded in July or August (Australian Bureau of Meteorology, www.bom.gov.au), removing the possibility of freshwater influx as the cause of this movement pattern. Despite the lack of a measurable parameter, it appears that a change within the environment must have occurred to trigger movement and dispersal of most if not all individuals.

The results of the present study raise several questions about short- and long-term use of freshwater habitats by barramundi. The ecological implications of long-term residence in freshwater should be considered as an aspect of the life history of this species. It is unclear whether individuals in Mission Billabong remain in freshwater habitats for the majority (or entirety) of their life and what implications this behaviour would have for freshwater populations. For example, studies of otolith chemistry suggest that barramundi populations have a high dependence on freshwater systems for portions of their life history (McCulloch et al. 2005, Milton et al. 2008). In addition, Robins et al. (2006) revealed higher growth rates for barramundi in years of greater flooding and Milton et al. (2008) suggested that growth of immature individuals was enhanced by access to productive freshwater regions. Therefore, use of freshwater habitats may be crucial to barramundi populations by providing productive habitat exploited for fast growth. Longer-term data should be collected to help define larger-scale movement and dispersal patterns through time and better define activity space and habitat/food resource use of these populations.

\section{LITERATURE CITED}

Arrington DA, Winemiller KO (2006) Habitat affinity, the seasonal flood pulse, and community assemblage in the littoral zone of a Neotropical floodplain river. J N Am Benthol Soc 25:126-141

Balcombe SR, Arthington AH, Foster ND, Thoms MC, Wilson GG, Bunn SE (2006) Fish assemblages of an Australian dryland river: abundance, assemblage structure and recruitment patterns in the Warrego River, Murray-Darling Basin. Mar Freshw Res 57:619-633

Bayley PB (1989) Aquatic environments in the Amazon Basin, with an analysis of carbon sources, fish production and yield. Publ Spec Can Sci Halieut Aquat 106:309-408

> Castello L (2008) Lateral migration of Arapaima gigas in floodplains of the Amazon. Ecol Freshw Fish 17:38-46

Davis TLO (1986) Migration patterns in barramundi, Lates calcarifer (Bloch), in Van Diemen Gulf, Australia, with estimates of fishing mortality in specific areas. Fish Res 4: 243-258

de Lestang P, Griffin RK, Allsop Q (2004) Assessment of the post-release survival and stress physiology of barramundi (Lates calcarifer). Fisheries Report 73. Department of Business, Industry and Resource Development, Darwin

de Lestang P, Allsop QA, Grace BS (in press) Using radiotelemetry to measure survival of line-caught barramundi: effects of anatomical hooking location and season. In: Mesa M (ed) Advances in fish tagging and marking technology. N Am Fish Soc Publ

> Douglas MM, Bunn SE, Davies PM (2005) River and wetland food webs in Australia's wet-dry tropics: general principles and implications for management. Mar Freshw Res 56:329-342

Dunstan DJ (1962) The barramundi in New Guinea waters. Papua New G Agr J 15:23-31

$>$ Fernandes CC (1997) Lateral migration of fishes in Amazon floodplains. Ecol Freshw Fish 6:36-44

- Galacatos K, Barriga-Salazar R, Stewart DJ (2004) Seasonal and habitat influences on fish communities within the lower Yasuni River basin of the Ecuadorian Amazon. Environ Biol Fish 71:33-51

Griffin RK (1987) Life history, distribution and seasonal migration of barramundi in the Daly River, Northern Territory, Australia. Am Fish Soc Symp 1:358-363

Griffin RK (1994) Radio tracking studies of barramundi (sea bass) Lates calcarifer, in the Mary River, Northern Territory, Australia. In: Chou LM, Munro AD, Lam TJ and others (eds) The Third Asian Fisheries Forum. Asian Fisheries Society, Manila, Philippines

$>$ Keenan CP (1994) Recent evolution of population structure in Australian barramundi, Lates calcarifer (Bloch): an example of isolation by distance in one dimension. Aust J Mar Freshw Res 45:1123-1148

- Makrakis MC, Miranda LE, Makrakis S, Xavier AMM, Fontes HM, Morlis WG (2007) Migratory movements of pacu, Piaractus mesopotamicus, in the highly impounded Paraná River. J Appl Ichthyol 23:700-704

McCulloch M, Cappo M, Aumend J, Müller W (2005) Tracing the life history of individual barramundi using laser ablation MC-ICP-MS Sr-isotopic and Sr/Ba ratios in otoliths. Mar Freshw Res 56:637-644

Milton D, Halliday I, Sellin M, Marsh R, Staunton-Smith J, Woodhead J (2008) The effect of habitat and environmental history on otolith chemistry of barramundi Lates calcarifer in estuarine populations of a regulated tropical river. Estuar Coast Shelf Sci 78:301-315

Moore R, Reynolds LF (1982) Migration patterns of barra- 
mundi Lates calcarifer (Bloch), in Papua New Guinea. Aust J Mar Freshw Res 33:671-682

Osborne R, Bettoli PW (1995) A reusable ultrasonic tag and float assembly for use with large pelagic fish. N Am J Fish Manag 15:512-514

Pender PJ, Griffin RK (1996) Habitat history of barramundi Lates calcarifer in a north Australian river system based on barium and strontium levels in scales. Trans Am Fish Soc 125:679-689

Perna C, Pearson RG (2008) Temporal dynamics of fish assemblages in small seasonal streams in the Queensland tropics. Aust J Zool 56:65-75

Pusey BJ, Arthington AH, Read MG (1995) Species richness and spatial variation in fish assemblage structure in two rivers of the wet tropics of northern Queensland, Australia. Environ Biol Fishes 42:181-199

Rayner TS, Pusey BJ, Pearson RG (2009) Spatio-temporal dynamics of fish feeding in the lower Musgrave River, north-eastern Queensland: the influence of seasonal flooding, instream productivity and invertebrate abundance. Mar Freshw Res 60:97-111

Rayner TS, Pusey BJ, Pearson RG, Godfrey PC (2010) Food web dynamics in an Australian wet tropics river. Mar Freshw Res 61:909-917

Editorial responsibility: Angela Arthington, Nathan, Queensland, Australia
Robins JB, Halliday IA, Staunton-Smith J, Mayer DG, Sellin $M$ (2005) Freshwater-flow requirements of estuarine fisheries in tropical Australia: a review of the state of knowledge and application of a suggested approach. Mar Freshw Res 56:343-360

Robins JB, Halliday IA, Staunton-Smith J, Mayer DG, Sawnock W, Sellin M (2006) Variable growth rates of a tropical estuarine fish species (barramundi Lates calcarifer Bloch) under different freshwater flow conditions. J Fish Biol 69:379-391

Rodriguez MA, Lewis WM Jr (1997) Structure of fish assemblages along environmental gradients in floodplain lakes of the Orinoco River. Ecol Monogr 67:109-128

Russell DJ, Garrett RN (1988) Movements of juvenile barramundi Lates calcarifer (Bloch), in north-eastern Queensland. Aust J Mar Freshw Res 39:117-123

Saint-Paul U, Zuanon J, Villacorta Correa MA, García M, Fabré NN, Berger U, Junk WJ (2000) Fish communities in central Amazonian white- and blackwater floodplains. Environ Biol Fishes 57:235-250

Tedesco PA, Hugueny B, Oberdorff T, Dürr HH, Mérigoux S, de Mérona B (2008) River hydrological seasonality influences life history strategies of tropical riverine fishes. Oecologia 156:691-702

Submitted: July 1, 2010; Accepted: February 18, 2011

Proofs received from author(s): April 9, 2011 